\title{
Green Technical Methods for Treatment of Waste Water Using Microalgae and its Application in the Management of Natural Water Resources: A Review
}

\author{
SAPNA N. NANDESHWAR ${ }^{1}$ and GANESH D. SATPUTE ${ }^{2}$ \\ 'Sevadal Mahila Mahavidyalaya, Sakkardara Square, Nagpur-009, India. \\ ${ }^{2}$ Shri Govindrao Munghate Arts and Science College, Kurkheda, India. \\ http://dx.doi.org/10.12944/CWE.9.3.34
}

(Received: June 13, 2014; Accepted: August 04, 2014)

\begin{abstract}
Water covers $71 \%$ of the Earth's surface, and is vital for all known forms of life. But only $2.5 \%$ of the Earth's water is freshwater. Due to industrialization and Urbanization it is becoming more polluted and risk of this polluted water consumption and its sanitation problem is increasing day to day in most of the developing countries, so it has become anessential need for today's environment to protect water from getting polluted or develop its cost effective remedial method for its protection. Literature survey was done to find out the new, low-cost waste water treatment methods in which we had found that Microalgae has the natural wastewater treatment properties. It has the self cleansing power due to which it abstracts Nitrate $99 \%$, sulphate $84 \%$ and Phosphate $73 \%$ for its growth and development. During their growth they trap sun light and $\mathrm{CO}_{2}$ from the environment for their photosynthesis. In the mean time of review of literature we had found that waste water treatment using microalgae has number of positive applications over the conventional methods as it is useful in Wastewater treatment, $\mathrm{CO} 2$ sequestration, Cost effective, Sanitation and also in the production of renewable sources of energy such as Biodiesel, Biofuel, Glycerol, Methane gas, Hydrogen gas, Biofertilizers etc. The overall review has concluded that this Green technical method for treatment of municipal waste water using microalgae should be applied in all developing and developed countries for wastewater treatment so as to protect the environmental pollution causing due to waste water from industrial and Societies effluents.
\end{abstract}

Key words: Wastewater Treatment, Microalgae, Renewable, Biomass, biofuel, Green Techniques.

\section{INTRODUCTION}

Water is one of the most important substances on earth. All plants and animals must have water to survive. If there was no water there would be no life on earth ${ }^{1}$. It covers $71 \%$ of the Earth's surface, and is vital for all known forms of life. But only $2.5 \%$ of the Earth's water is fresh water.Rapid urbanization and industrialization releases enormous volumes of wastewater, which is increasingly utilized as a valuable resource for irrigation in urban and peri-urban agriculture. It drives significant economic activity, supports countless livelihoods particularly those of poor farmers, and substantially changes the water quality of natural water bodies ${ }^{2}$. Due to industrialization and Urbanization it is becoming more polluted and risk of this polluted water consumption and its sanitation problem is increasing day to day in most of the developing countries. This growing problem of water scarcity has significant negative influence on economic development, human livelihoods, and environmental quality throughout the world ${ }^{3}$. So it has become anessential need for today's environment to protect water from getting polluted or develop its cost effective remedial method for its protection.

The various conventional methods for waste water treatment are present since the ancient time $e^{4-10}$ but they are very costly and not economical. 
So the new green technical methods are being introduced to overcome the conventional methods of waste water treatment ${ }^{12-15}$. The present study is related with new green technical methods which are proving them to be superior over the conventional methods; out of them low cost waste water treatment using microalgae is the potential one. Literature survey was done to find out the new methods of waste water treatment using microalgae and their development till now and to find out its application in management of natural water resources.

\section{Background}

The concept of wastewater treatment using microalgae was firstly proposed by Oswald in the $1950^{16,17}$ and the concept was later expanded to propose use of this system for energy production through harvesting and utilization of algal biomass ${ }^{18}$. Shirai F, et. al. in the year 1998 who investigate the treatment of Soy Sauce effluent including four types of microalgae ${ }^{19}$ in which they applied this method for the fermentation of ethanol from the biomass which was obtained by harvesting microalgae. After that so many scientist turned their research work to treat various industrial and municipal waste water using different types of microalgae ${ }^{20-26}$.

\section{Green Aspects of Wastewater treatment using Microalgae}

Wastewater treatment using microalgae shows its potential ability towards the greenery ofenvironment and its suitability for applying it in green technical methods. It obeys most of the basic principles of green chemistry which was given by Paul T. Anastas ${ }^{27}$. The green applications of this technique are listed below.

1. Removal of Nutrient pollutants and Heavy Metals

2. Cost effective

3. Low energy requirement

4. Production of Useful Biomass

5. Reduction in sludge Formation

6. Algae contain more than $50 \%$ of oil in its biomass

7. They provide much higher yields of biomass and fuel

8. 10-100 times higher than comparable energy crops

9. They can be grown under condition which is unsuitable for conventional crop production.

\section{Nutrient removal capability of Microalgae}

A major requirement in wastewater treatment is the removal of nutrients and toxic metals to acceptable limits prior to discharge and reuse ${ }^{28}$. Algae are autotrophs, i.e. they can synthesize organic molecules themselves from inorganic nutrients. A stoichiometric formula for the most common elements in an average algal cell is $\mathrm{C} 106 \mathrm{H} 181045 \mathrm{~N} 16 \mathrm{P}$, and the elementsshould be present in these proportions in the medium for optimal growth ${ }^{29}$. Microalgae have been proven to be efficient in removing nitrogen, phosphorus, and toxic metals from a wide variety of wastewaters ${ }^{30,31,32}$. There are extensive studies of algae growth in municipa| ${ }^{33,34}$, agricultura| $\left.\right|^{35,36}$, and industrial wastewaters ${ }^{37,38}$. Substantial amounts of nutrient removal and algae biomass production were obtained in these studies. Hence, controlled microalgae cultivation shows promise as a potential biological treatment method for wastewater.

This integrated wastewater treatment and biofuel production system can thus benefit the community as well as the environment ${ }^{39}$.

Nitrogen Removal

Nitrogen is a critical nutrient required in the growth of all organisms. Organic nitrogen is found in a variety of biological substances, such as peptides, proteins, enzymes, chlorophylls, energy transfer molecules (ADP, ATP), and genetic materials (RNA, $\mathrm{DNA})^{40}$. Organic nitrogen is derived from inorganic sources including nitrate (NO3_), nitrite (NO2_), nitric acid (HNO3), ammonium (NH4p), ammonia $(\mathrm{NH} 3)$, and nitrogen gas (N2). Micro- algae play a key role in converting inorganic nitrogen to its organic form through a process called assimilation. In addition, cyanobacteria are capable of converting atmospheric nitrogen into ammonia by means of fixation.

\section{Phosphorous Removal}

Phosphorus is also a key factor in the energy metabolism of algae and is found in nucleic acids, lipids, proteins, and the intermediates of carbohydrate metabolism. Inorganic phosphates play a significant role in algae cell growth and metabolism. Phosphates are transferred by energized transport across the plasma membrane of the algal cell. Not only are inorganic forms of phosphorus utilized by microalgae, but some varieties of algae are able 
to use the phosphorus found in organic esters for growth $^{41}$.

\section{Other Nutrients}

Although, nitrogen and phosphorous are the two main nutrients of concern in eutrophication, being limiting factors in most growth scenarios ${ }^{42}$, other micronutrients, including silicon and iron, can affect the abundance of phytoplankton communities ${ }^{43}$. How- ever, many of the micronutrients are toxic to most algae species at high concentrations. Some of them also form precipitates with other essential elements and reduce their availability. However some algae strains are particularly tolerant to heavy metals and their potential to absorb metals has been demonstrated $^{44}$.

\section{Low energy requirement}

Traditional wastewater treatment processes involve the high energy costs of mechanical aeration to provide oxygen to aerobic bacteria to consume the organic compounds in the wastewater, whereas in algae based wastewater treatment, algae provides the oxygen for aerobic bacteria. Aeration is an energy intensive process, accounting for 45 to $75 \%$ of a wastewater treatment plant's total energy costs. Algae provide an efficient way to consume nutrients and provide the aerobic bacteria with the needed oxygen through photosynthesis. Roughly one $\mathrm{kg}$ of $B O D$ removed in an activated sludge process requires one $\mathrm{kWh}$ of electricity for aeration, which produces one $\mathrm{kg}$ of fossil $\mathrm{CO} 2$ from power generation (Oswald, 2003). By contrast, one kg of BOD removed by photosynthetic oxygenation requires no energy inputs and produces enough algal biomass to generate methane that can produce one $\mathrm{kWh}$ of electric power (Oswald, 2003).

\section{Cost effective}

It has been shown to be a more cost effective way to remove biochemicaloxygen demand, pathogens, phosphorus and nitrogen than activated sludge process and other secondary treatment processes (Green et al., 1996) ${ }^{45}$

\section{Production of Useful Algal Biomass}

The resulting algae biomass is a source of useful products such as biodiesel. Previous research in the early 1990's by the National Renewable Energy Laboratory (NREL) showed that under controlled conditions algae are capable of producing 40 times the amount of oil for biodiesel per unit area of land, compared to terrestrial oilseed crops such as soy and canola (Sheehan et al., 1998) ${ }^{46}$. However, their results also showed that large-scale algae cultivation for energy production was uneconomical at that time and suggested future research into waste - stream integration (Sheehan et al., 1998). It is hoped that the economics will be ultimately improved by combining biodiesel feedstock production with agricultural or municipal wastewater treatment and $\mathrm{CO} 2$ fixation.

\section{Reductions in Sludge Formation}

In conventional wastewater treatment systems the main aim is to minimize or eliminate the sludge. Industrial effluents are conventionally treated using a variety of hazardous chemicals for $\mathrm{pH}$ correction, sludge removal, colour removal and odour removal. Extensive use of chemicals for effluent treatment results in huge amounts of sludge which forms the so called hazardous solid waste generated by the industry and finally disposed by depositing them in landfills. In algae wastewater treatment facilities, the resulting sludge with algal biomass is energy rich which can be further processed to make biofuel or other valuable products such as fertilizers. Algal technology avoids use of chemicals and the whole process of effluent treatment is simplified. There is considerable reduction in sludge formation ${ }^{15}$.

\section{The GHG emission Reduction}

Carbon, in the form of carbon dioxide, may be fixed from the atmosphere and industrial exhaust gases through the photosynthetic activity of autotrophic microalgae. Carbon can be also utilized in the form of soluble carbonates for cell growth, either by direct uptake or conversion of carbonate to free carbon dioxide through carbo anhydrase activity. The use of algae to mitigate carbon dioxide from flue gases is another research focus and, if effective, could benefit both the environment and biofuel production ${ }^{28}$.

The Us Environmental Protection Agency (EPA) has specifically identified conventional wastewater treatment plants as major contributors to greenhouse gases ${ }^{48}$. Algae based waste water treatment also releases $\mathrm{CO} 2$ but the algae consume more $\mathrm{CO} 2$ while growing than that is being released 
by the plant, this makes the entire system carbon negative.

\section{OtherApplications}

Algae can be used to make bioethanol and biobutanol and by some estimates can produce vastly superior amounts of vegetable oil, compared to terrestrial crops grown for the same purpose. Algae can be grown to produce Hydrogen. In 1942 a German researcher named Hans Gaffron, while working at the University of Chicago, observed that the algae he was studying, Chlamydomonas reinhardtii (a green algae), would sometimes switch from the production of Oxygen to the production of Hydrogen ${ }^{47}$. Algae can be grown to produce biomass, which can be burned to produce heat and electricity.

\section{RESULT}

Microalgae have the natural wastewater treatment properties. It has the self cleansing power due to which it abstracts Nitrate around
$90 \%$, sulphate $80 \%$ and Phosphate $70 \%$ for its growth and development. During their growth they trap sun light and $\mathrm{CO}_{2}$ from the environment for their photosynthesis. In the mean time of review of literature we had found that waste water treatment using microalgae has number of positive applications over the conventional methods as it is useful in Wastewater treatment, CO2 sequestration, Cost effective, Sanitation and also in the production of renewable sources of energy such as Biodiesel, Biofuel, Glycerol, Methane gas, Hydrogen gas, Biofertilizers etc.

\section{CONCLUSIONS}

The overall review has concluded that this Green technical method for treatment of municipal waste water using microalgae should be applied in all developing and developed countries for wastewater treatment so as to protect the environmental pollution causing due to waste water from industrial and domestic effluents.

\section{REFERENCES}

1. http://www.health.gov.au/internet/ publications/publishing.nsf/Content/ohpenhealth-manual-atsi-cnt-I ohp-enhealthmanual-atsi-cnt-I-ch6 ohp-enhealth-manualatsi-cnt-I-ch6.1

2. Marshall, F.M., Holden, J., Ghose, C., Chisala, B., Kapungwe, E., Volk, J., Agrawal, M., Agrawal, R., Sharma, R.K., Singh, R.P., 2007. Contaminated Irrigation Water and Food Safety for the Urban and Peri-urban Poor: Appropriate Measures for Monitoring and Control from Field Research in India and Zambia, Incpetion Report DFID Enkar R8160, SPRU, University of Sussex.<www. pollutionandfood.net>.

3. http://www.studymode.com/essays/WaterScarcity-In-India-1248849.html

4. Frank R. Spellman, Handbook of water and wastewater treatment plant operations, second edition Top of Form

5. Bottom of Form

6. http://www.fao.org/docrep/t0551e/t0551e05. htm\#3.2 conventional wastewater treatment processes
7. Pawar Avinash Shivajirao, Treatment Of Distillery Wastewater Using Membrane Technologies, International Journal of Advanced Engineering Research and Studies E-ISSN2249-8974

8. Narmadha D and Mary Selvam Kavitha V, Treatment Of Domestic Waste Water Using Natural Flocculants, Int. J. LifeSc. Bt \& Pharm. Res. (2012)

9. Edmond O'Reilly, 1,2 Shane Fox, 1 Michael Rodgers, 3 Eoghan Clifford, Research developments in the on-site treatment of wastewater, http://www.epa-pictaural.com/ media/wwater12/paper/edmondOReilly.pdf

10. Environmental Protection Agency, Wastewater treatment manuals, Primary, secondary and tertiary treatment.

11. Hithman, 20: Chapter 2, Waste water treatment.

12. H. Zhou and D.W. Smith, Advanced technologies in water and wastewater treatment., J. Environ. Eng. Sci. 1: (2002)

13. I. Turovskiy, New Techniques for Wastewater and Sludge Treatment in Northern Regions, 
December28,2000

14. Chapter 8 Wastewater Treatment Technologies Development Document for the CWT Point Source Category.

15. New Technologies in Wastewater Treatment, Oilgae, Wednesday, January 15, 2014, http:// www.oilgae.com/algae/cult/sew/new/new. html

16. Oswald, W., Gotass, H., 1957. Photosynthesis in sewage treatment. Journal Name: Trans. Amer. Soc. Civil Engrs.; (United States); Journal Volume: 122, Medium: X; Size: Pages: 73.

17. Oswald, W.J., High rate pond in waste disposal Dev. Ind. Biotechnol., 4: 112-119 (1963).

18. Benemann, J.R., Weissman, J.C., Koopman, B.L., Oswald, W.J., Energy Production with Microalgae. Nature, 19-23 (1977).

19. F. Shirai, K. Kunii, C. Sato, Y. Teramoto, E. Mizuki, S. Murao, S. Nakayama, Cultivation of microalgae in the solution from the desalting processes of soy sauce waste treatment and utilization of the algal biomass for ethanol fermentation, World journal of Microbiology and Biotechnology, (1998).

20. Karin Larsdotter (2006): Microalgae for phosphorus removal from wastewater in a Nordic climate. A doctoral thesis from the School of Biotechnology, Royal Institute of Technology, Stockholm, Sweden. ISBN: 917178-288-5

21. Leslie R. Kryder, Microalgae for Wastewater Treatment and Reuse, CE 598 Water Reuse, November, 2007.

22. Mr. Raffaello Garofalo, Algae and aquatic biomass for a sustainable production of 2nd generation biofuels, AQUAFUEL FP7 2413012 , Coordination Action, FP7 Energy ; 1 (2009)

23. Yan Zhou, Improving Algal Biofuel Production Through Nutrient Recycling And Characterization Of Photosynthetic Anomalies In Mutant Algae Species, Thesis, University of Illinois at Urbana-Champaign, 2010.

24. Christenson, Logan, "Algal Biofilm Production and Harvesting System for Wastewater Treatment with Biofuels By-Products" (2011).
25. Ahmed Al Darmaki, L Govindrajan, Sahar Talebi, Sara Al-Rajhi, Tahir Al-Barwani, Zainab Al-Bulashi, Cultivation and Characterization of Microalgae for Wastewater Treatment, Proceedings of the World Congress on Engineering 2012 Vol I, WCE 2012, July 4 - 6, 2012, London, U.K.

26. Buchanan1, AN, Bolton1, N, Moheimani2, N, Svoboda1, IF, Grant3, T, Batten4, D, Cheng1, NN, Borowitzka2, M, and Fallowfield1 HJ., Algae For Energy And Feed: A Wastewater Solution. A Review (Project 4A-101 112), January 2013

27. Green Chemistry-Green Engineering, 2. Green Chemistry and Technology for Sustainable Development. Basic Principles and Applications http://www.chem. uoa.gr/courses/organiki_1/greenchem/ PDF_en/GREEN-CHEMISTRY-PDF-2INTRODUCTION-2012.pdf

28. Ting Cai 1, StephenY.Park 1, YeboLi, Nutrient recovery from wastewater streams by microalgae: Status and prospects, Renewable and Sustainable Energy Reviews 19: 360-369 (2013).

29. Oswald, W.J. Micro-algae and waste-water treatment, in Micro-algal biotechnology, M.A. Borowitzka and L.J. Borowitzka, Editors. Cambridge University press: Cambridge. $p$. 305-328 (1988).

30. Zhou W, Min M, Li Y, Hu B, Ma X, Cheng Y, et al. A hetero-photoautotrophic two-stage cultivation process to improve wastewater nutrient removal and enhance algal lipid accumulation. Bioresource Technology; 110:448-55 (2012).

31. Boelee NC, Temmink H, Janssen M, Buisman CJN, Wijffels $\mathrm{RH}$. Scenario analysis of nutrient removal from municipal wastewater by microalgal biofilms. Water, 4: 460-73 (2012).

32. Sturm BSM, Lamer SL. An energy evaluation of coupling nutrient removal from wastewater with algal biomass production. Applied Energy ; 88: 3499-506 (2011).

33. LiY, ChenY, ChenP, MinM, ZhouW, MartinezB, et al. Characterization of a microalga Chlorella sp. Well adapted to highly concentrated municipal waste- water for nutrient removal and biodiesel production. Bioresource 
Technology; 102: 5138-44 (2011).

34. Chi Z, Zheng Y, Jiang A, Chen S. Lipid production by culturingoleaginous yeast and algae with food waste and municipal waste water inanintegrated process. Applied Biochemistry and Biotechnology ;165: 44253 (2011).

35. Mulbry W, Kondrad S, Pizarro C, Kebede-West head $E$. Treatment of dairy manure effluent using fresh water algae: algal productivity and recovery of manure nutrient susingpilotscalealgalturf scrubbers. BioresourceTechnology ; 99: 8137-42 (2008).

36. MulbryW, Kondrad S,Buyer J, Luthria D.Optimization of anoil extraction process for algae from the treatment of manure effluent. Journal of the American Oil Chemists'Society; 86: 909-15 (2009).

37. Chinnasamy S, Bhatnagar A, Hunt RW, Das KC. Microalgae cultivationina waste water dominated by carpet mill effluents for bio fuel applications. Bioresource Technology; 101: 3097-105 (2010).

38. Markou G, Georgakakis D. Cultivation of filamentouscyano bacteria (blue- green algae) in agro-industrial wastes and wastewaters: are view.Applied Energy; 88: 3389-401 (2011).

39. Brick W. Griffiths, Removal And Utilization Of Wastewater Nutrients For Algae Biomass And Biofuels, Utah State University 2010

40. Barsanti L, Gualtieri P. Algae: anatomy, biochemistry, and biotechnology. Boca Raton: CRC Press; 2006.
41. Kuenzler EJ. Glucose-6-phosphate utilization by marine algae. Journal of Phycology ; 1 : 156-64 (1965).

42. Anderson DM, Glibert PM, Burkholder JM. Harmful algal blooms and eutrophication: nutrient sources, composition, and consequences. Estuaries; 25: 704-26 (2002).

43. Hecky RE, Kilham P. Nutrient limitation of phytoplankton in freshwater and marine environments: Reviews of recent evidence on the effects of enrich- ment. Limnology and Oceanography, 33: 796-822 (1988).

44. Mehta SK, Gaur JP. Use of algae for removing heavy metal ions from wastewater: progress and prospects. Critical Reviews in Biotechnology; 25: 113-52 (2005).

45. Sheehan, J., Dunahay, T., Benemann, J. and Roessler, P.: 1998, A Look Back at the U.S. Department of Energy's Aquatic Species Program - Biodiesel From Algae, Golden, $\mathrm{CO}$, National Renewable Energy Institute, NREL/TP-580-24190, 328 pp.

46. Gaffron, H. and Rubin, J.: , 'Fermentative and photochemical production of hydrogen in algae', Journal of General Physiology 20, 219-240 (1942).

47. Elizabeth A. Scheehle, Improvements to the U.S. Wastewater Methane and Nitrous Oxide Emissions Estimates, U.S. Environmental Protection Agency, Office of Air and Radiation, Non-CO2 Greenhouse Gases and Sequestration Branch, Washington DC. 